\title{
Heavy Metal Analysis of Soil Around Mine Sites in Ameri, Enyigba, and Ishiagu in Ebonyi State
}

\author{
Emmanuel Nyela Musa* $\quad$ Nasirudeen Mohammed Baba \\ Department of Chemistry, Kaduna State University, Kaduna, Nigeria
}

\begin{abstract}
Heavy metal contamination of soil, water and crops, and their health impact on residents, is a persistent social issue, and several studies have identified health risks of residents living near operational and abandoned mines. In this study, eight (8) homogenous soil samples were collected from mining sites in Enyigba, Ameri and Ishiagu in Ebonyi State, south-eastern Nigeria and analyzed for $\mathrm{Pb}, \mathrm{Zn}, \mathrm{Ni}, \mathrm{Co}, \mathrm{Mn}$, and $\mathrm{Ag}$. Metal concentration was determined using the Atomic Absorption Spectrometry (AAS) technique. Result for the heavy metals followed the trend: $\mathrm{Mn}>\mathrm{Zn}>\mathrm{Pb}>\mathrm{Ni}>\mathrm{Ag}>\mathrm{Co}$ for the soil analyzed. However, lead $(\mathrm{Pb})$ was only detected in Enyigba mining sites. Metal concentrations in some samples indicated soil contamination from $\mathrm{Mn}, \mathrm{Pb}, \mathrm{Zn}, \mathrm{Ni}$, and $\mathrm{Ag}$, which showed high concentration than the United States Environmental Protection Agency (US EPA) (1986) permissible limit for heavy metals in agricultural soil; only Co was recorded at a concentration below the US EPA (1986) permissible limit for all samples analyzed. The variations observed for the heavy metals suggest that both geologic and anthropogenic activities may be responsible for their distribution.
\end{abstract}

Keywords: Anthropogenic; contamination, geologic; health risks; heavy metals; mines; soil.

DOI: $10.7176 / \mathrm{JEES} / 9-10-12$

Publication date:October $31^{\text {st }} 2019$

\section{INTRODUCTION}

Like the majority of human activities, mining operations produces waste materials which contain trace metals that could be absorbed by soils around the mine site and its surroundings. One of the major sources of metals in the soil in Ebonyi State is the background geochemistry. The State is highly mineralized and deposits of $\mathrm{Pb}, \mathrm{Zn}, \mathrm{etc}$. are abundant (Omaka, O. N., 2008). Mining of mineral resources and related activities results in extensive soil damage, altering microbial communities and affecting vegetation leading to destruction of vast amount of land. Metals released to the atmosphere from mining activities travel long distances and are deposited on the soil, vegetation and water. These metal ions, which are not degraded, persist and are retained in the ecosystem indefinitely (Amos-Tautuaet al., 2013; Itumohet al., 2013). One of the ubiquitous sets of chemical elements that abound in the environment is the heavy metals (Sabir, S.M., Khan,S.W. and Hayat, I., 2003). Significant amounts of heavy metals in the environment can contaminate waters and may accumulate in soil. Plants which take up nutrients in soil also absorb such toxicants. Since plants play a major role as producers in the food chain, the introduction of such chemicals into the environment then affects animals. Ingestion of these contaminants by animals causes deposition of residues in the animals (Matthew, M.M., Henke, R. and Atwood, A., 2002). The major environmental impacts from waste disposal can lead to the loss of productive land following its conversion to a waste storage area, and the introduction of sediment, acidity, and other contaminants into surrounding surface and groundwater; from water running over exposed problematic or chemically reactive wastes and resulting in the destruction of existing vegetation and soil profile (Matthew, M.M., Henke, R. and Atwood, A., 2002). This impending degree of environmental pollution as a result of mining activities impedes the healthy growth of the communities affected, poses threats to vegetation which absorbs moisture from the soil, to animals who consume the plants as food and to humans who consume these animals as well as the plants. The totality of mining activities directly or indirectly adversely affects the food chain negatively. Metals are potential environmental contaminants that can result to various human health problems when in excess in the food, water and in the air (Itumohet al., 2011). They are given special attention throughout the world due to their toxic effects even at very low concentrations (Salama, A. K. and Radwan, M. A., 2005) or at high concentrations (Omakaet al., 2012). Today, several cases of human diseases, disorders, malfunctions and malformation of organs due to metal toxicity have been reported (Omaka, O. N., 2012). The chemical investigation of the soil in the communities around these mine sites will provide information on the threat level that these contaminants poses to plants, animals and humans and the economy if not checked. Chemical investigations of soils around mine sites conducted by other authors have been found in literature to contain heavy metals in an alarming threat level.

These heavy metals are those elements which have density more than $5 \mathrm{~g} / \mathrm{cm}^{3}$, atomic weight of $63.546 \mathrm{~g} / \mathrm{mol}$ to $200.590 \mathrm{~g} / \mathrm{mol}$ (Kennish, M J., 1992), and a specific gravity greater than 4.0 (Connell, D.W. and G.J. Miller, 1984). The distribution of these trace metals is a global threat to the environment as they are widely present in the earth's crust, in air, water and food (Matthew, M.M., Henke, R. and Atwood, A., 2002). Living organisms normally require some of these heavy metals up to certain limits (Kennish, M J., 1992), and in case excess accumulation occurs it leads to severe detrimental effects even in trace amounts. 


\section{MATERIALS AND METHODS \\ Apparatus}

Beakers, Whatman filter paper, Hot plate, Fume cupboard, Mortar and pestle, Sieve, sample bottles, Analytical weighing balance, Sample bags, Hand auger.

\section{Study Area}

The study area is located, between latitudes $6^{0} 09^{\prime} \mathrm{N}$ and $6^{0} 13^{\prime} \mathrm{N}$ and longitudes $8^{0} 04^{\prime} \mathrm{E}$ and $8^{0} 09^{\prime} \mathrm{E}$, covering an area of $64 \mathrm{~km}^{2}$. The area of study consists of cretaceous sediments of the Asu river group, dominantly shales, silty shales, limestones and volcanic rocks. The study area around Abakaliki is one of the well-known lead-zinc mineralized districts in Africa where soil and streams have developed from naturally enriched parent materials, including black shales, hydrothermally mineralized rocks and mine dumps (Itumohet al., 2013). In Ishiagu and Enyigba environs, lead and zinc mining has been going on for over fifty years, and in recent times its exploration has been intensified. The vegetation is dominated by grasses, shrubs and trees (e.g. palm trees, coconut, mango, and orange trees). The areas are leading producers of rice, yam, potatoes, cocoyam, maize, plantain and cassava.

Enyigba and Ameri districts are located within Abakaliki and Ikwo Local Government Areas while Ishiagu is situated in Ivo Local Government Area of Ebonyi State, South Eastern Nigeria. Ishiagu is located between latitudes $50^{\circ} 52^{\prime}$ to $50^{\circ} 60^{\prime} \mathrm{N}$ and longitudes $70^{\circ} 30^{\prime}$ to $70^{\circ} 37^{\prime \prime}$ and Enyigba is located at Latitude $6^{\circ} 10 / \mathrm{N}-6^{\circ} 13$ / $\mathrm{N}$ and Longitude $8^{\circ} 07 / \mathrm{E}-8^{\circ} 10 / \mathrm{E}$ and covers a surface area of $33.06 \mathrm{~km}^{2}$. The lead-zinc lode in the Enyigba district comprises of Enyigba, Ameri and Ameka (Onyeobi and Imeokparia, 2014). These lodes are located within the Abakaliki anticlinorium in the Lower 4 Benue Trough. The occurrences of lead-zinc in the study area are associated with saline water. Figure 1 below shows the lead-zinc lode in the Enyigba districts; Enyigba, Ameri and Ameka.

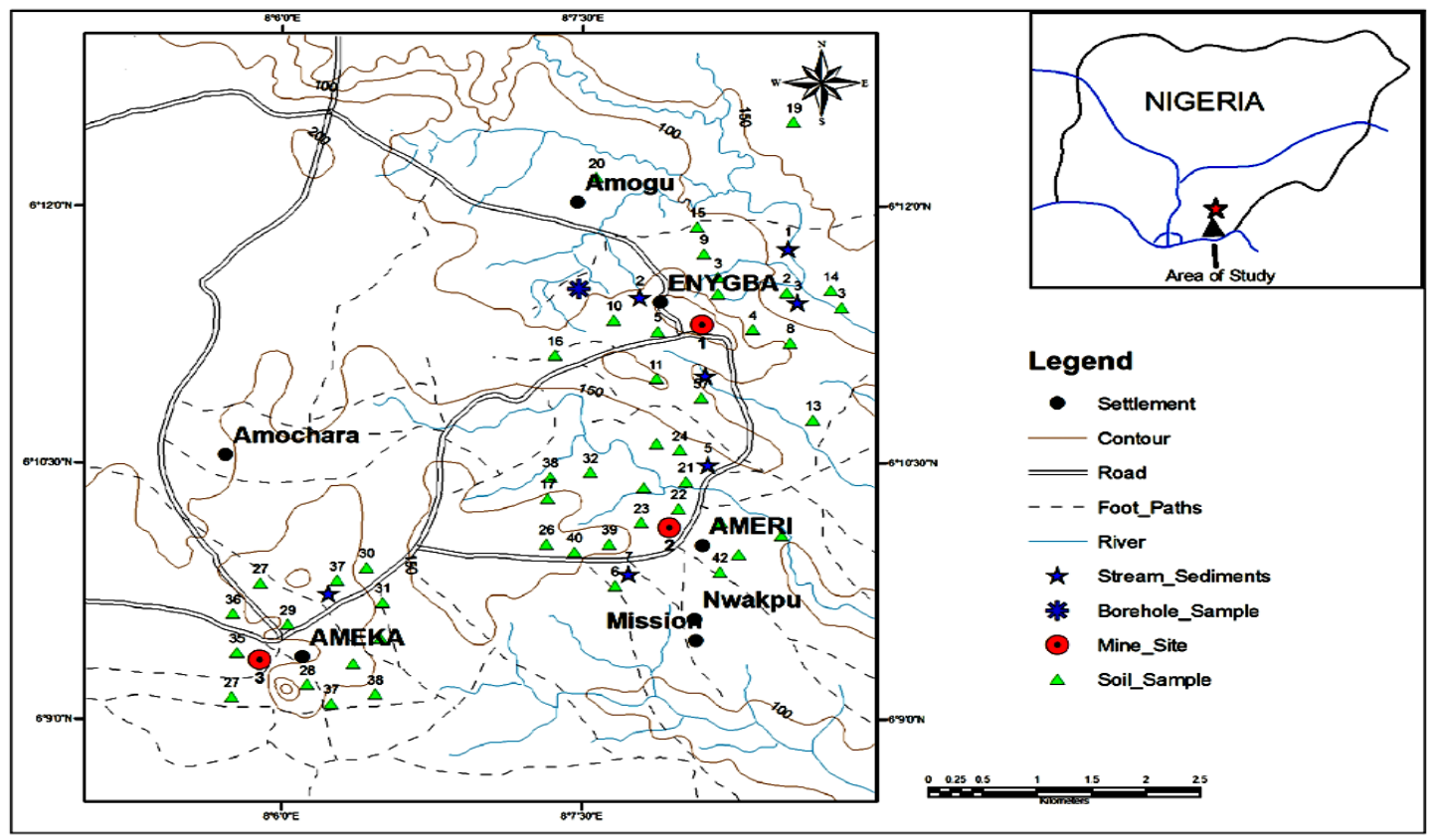

Figure 1: Sample location of the study area

Source: FG Volume 2 Issue 2, Apr. 2014 PP. 30-40 www.vkingpub.com (C) American V-King Scientific

\section{Sampling and Sample Preparation}

Publishing.

A total of eight soil samples were collected with a soil hand auger at a depth of $5 \mathrm{~cm}$ and distances of $20 \mathrm{~m}$ away from mine sites (Ameri, Enyigba, and Ishiagu). At each sampling site, triplicate collections within a $2 \mathrm{~m} \times 2 \mathrm{~m}$ grid were made from spots other than the first to ensure uniformity of soil samples from a site, out of which $1 \mathrm{~kg}$ was packaged in polyethylene bags. All the collected samples were properly marked and identified by their sampling locations using a Global Positioning System (GPS) receiver. The collected soil samples were taken to the laboratory for further processing.

The soil samples collected were sun-dried, grounded into fine powder using a mortar and pestle, and sieved through a $2 \mathrm{~mm}$ mesh to remove, residue stones and other plant materials to obtain a homogenous sample matrix. Close attention was paid to every sample to avoid cross-contamination.

Sample Digestion

$1 \mathrm{~g}$ each of the pulverized samples was carefully weighed into a $200 \mathrm{mls}$ digestion beaker upon which the addition 
of acids was followed. Thirty (30) mls of Conc $\mathrm{HCl}$ and $10 \mathrm{mls}$ of $\mathrm{Conc}_{\mathrm{HNO}}$ acids were added in the ratio of 3:1 (aqua regia) to the beakers. The samples were then subjected to heat on a hotplate for digestion. As the volume of the content in the beaker dropped to about $5 \mathrm{mls}$, aqua regia was added again and the samples were further digested a second time. That is, digestion was done twice on the samples, in order to ensure that the elements of interest are brought into solution. The digested samples were filtered into sample bottles and made up to mark with distilled water. Analysis of metals for $\mathrm{Pb}, \mathrm{Zn}, \mathrm{Ni}, \mathrm{Co}, \mathrm{Mn}$, and $\mathrm{Ag}$ were performed using atomic absorption spectrometer (AAS), Thermo Scientific ICE 3000 series. A matrix standard and blank was also prepared in the analysis.

\section{RESULT AND DISCUSSION}

The result of the heavy metal content of soil samples collected from three different locations in the mining community are shown in table 1.

Table 1: Concentrations of heavy metals in mine sites

\begin{tabular}{llllllll}
\hline $\begin{array}{l}\text { Sample } \\
\text { location }\end{array}$ & $\begin{array}{l}\text { Sample } \\
\text { ID }\end{array}$ & $\begin{array}{l}\text { Co } \\
(\mathbf{m g} / \mathbf{l})\end{array}$ & $\begin{array}{l}\mathbf{Z n} \\
(\mathbf{m g} / \mathbf{l})\end{array}$ & $\begin{array}{l}\text { Pb } \\
(\mathbf{m g} / \mathbf{l})\end{array}$ & $\begin{array}{l}\text { Ni } \\
(\mathbf{m g} / \mathbf{l})\end{array}$ & $\begin{array}{l}\text { Mn } \\
(\mathbf{m g} / \mathbf{l})\end{array}$ & $\begin{array}{l}\mathbf{A g} \\
(\mathbf{m g} / \mathbf{l})\end{array}$ \\
\hline Ameri & (A) & 0.381 & 3.916 & BDL & 2.025 & 5.416 & 1.562 \\
& (B) & 0.168 & 8.831 & BDL & 2.747 & 10.802 & 1.882 \\
& (C) & 0.213 & 1.480 & BDL & 1.894 & 2.391 & 1.519 \\
& (D) & 0.283 & 0.645 & BDL & 3.082 & 3.956 & 0.788 \\
& (E) & 0.524 & 1.184 & BDL & 2.451 & 5.637 & 1.259 \\
Enyigba & (F) & 0.317 & 0.984 & 4.056 & 2.473 & 9.703 & 1.038 \\
& (G) & 0.684 & 1.060 & 2.226 & 2.939 & 6.737 & 1.406 \\
Ishiagu & (H) & 0.609 & 0.849 & BDL & 2.181 & 5.975 & 1.278 \\
\hline
\end{tabular}

$\mathrm{BDL}=$ Below Detection Limit

\section{Cobalt Levels}

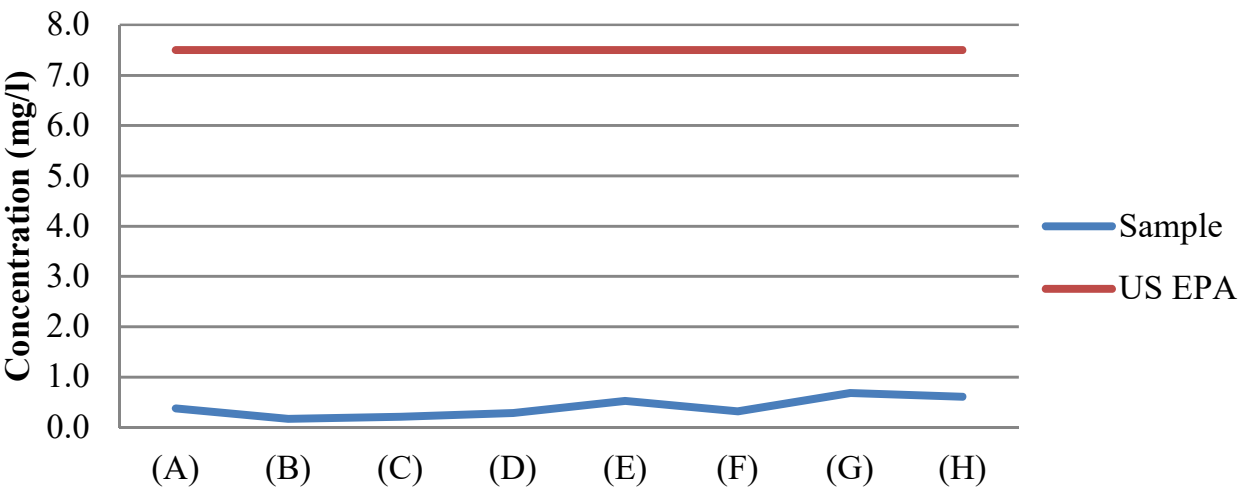

Figure 2: Cobalt concentrations in soil samples relative to US EPA permissible limits

The graphical illustration shown in figure 2 revealed that the concentration of Cobalt $(\mathrm{Co})$ in all the samples followed the order $(B)<(C)<(D)<(F)<(A)<(E)<(H)<(G)$. All soil samples showed concentration above the Bowen (1986) standard, but fell below the $7.50 \mathrm{mg} / \mathrm{l}(750 \mathrm{mg} / \mathrm{kg})$ of the United States Environmental Protection Agency (US EPA) limit permissible for domestic gardens, residential and agricultural areas. This suggests that the soil samples were not "in all contaminated" and could support agricultural activities, however, metal accumulation over a long period of time may occur leading to high metal level content. Similar studies by (Karaca A., 2004) showed that the concentration of cobalt in soil around mine sites fell below the $7.50 \mathrm{mg} / 1$ limit permissible set by the US EPA. 


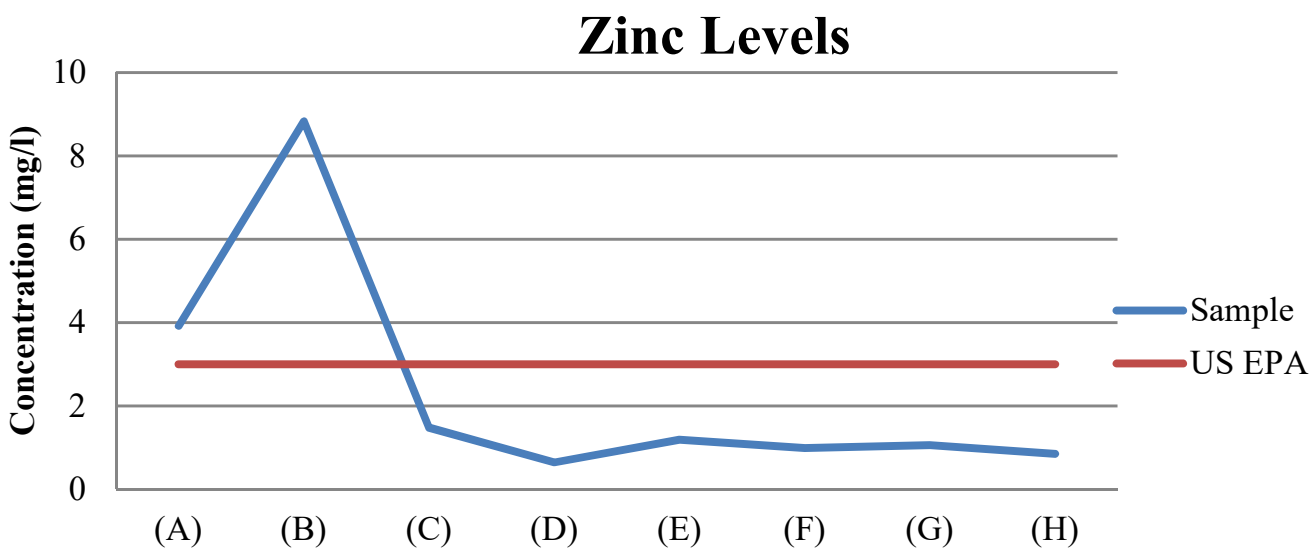

Figure 3: Zinc concentrations in soil samples relative to US EPA permissible limits

The Zinc (Zn) concentration for all the samples followed the order (D) $<$ (H) $<$ (F) $<$ (G) $<$ (E) $<$ (C) $<$ (A) $<$ (B) (figure 3). All soil samples showed concentration above $0.9 \mathrm{mg} / 1$ (90 mg/kg) set by Bowen (1979) except samples (D) from Enyigba and $(\mathrm{H})$ from Ishiagu which were below $0.9 \mathrm{mg} / \mathrm{l}$; while according to the US EPA (1986) and CEC (1986) permissible limits of $3.00 \mathrm{mg} / 1$ (300 mg/kg) for agricultural lands, only sample (A) and sample (B) from Ameri were higher than the permissible limits of $3.00 \mathrm{mg} / 1$ for agricultural lands. This suggests that the soil samples (A) and (B) in Ameri collected from the mine pit were contaminated and not healthy for agricultural practices. Similar results have been reported earlier by (During, R.A., Hob, T. and Gath, S., 2003; Su, D.C. and Wong, J.W.C., 2003) on their separate studies on the absorption and bioavailability of heavy metals in soils.

Nickel Levels

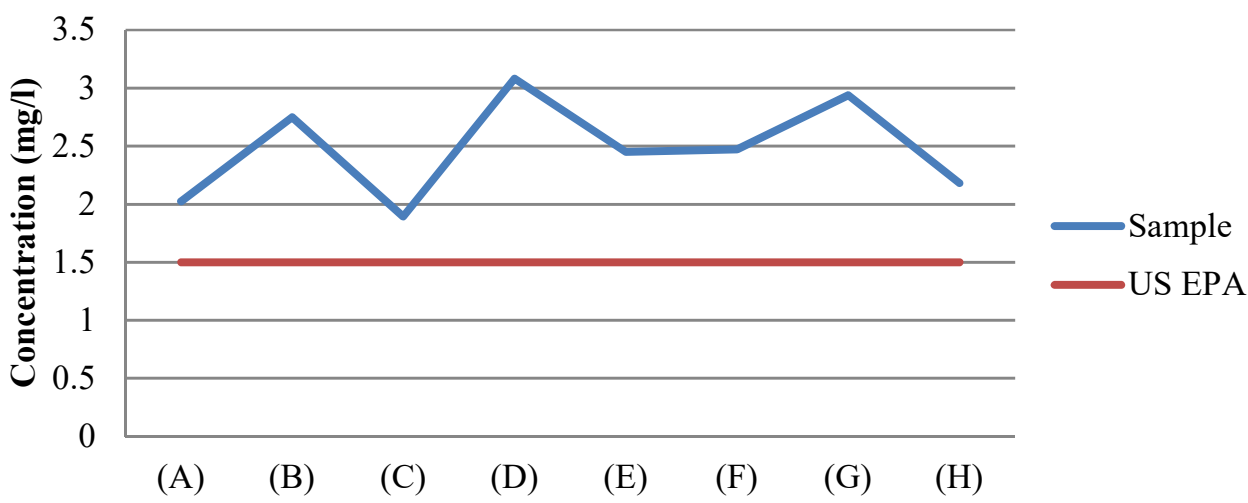

Figure 4: Nickel concentrations in soil samples relative to US EPA permissible limits

Figure 4 revealed that the Nickel $(\mathrm{Ni})$ concentration for all the samples ranged from $1.894 \mathrm{mg} / 1-3.082 \mathrm{mg} / \mathrm{l}$ $\left(189.4 \mathrm{mgkg}^{-1}-308.2 \mathrm{mgkg}^{-1}\right)$ in the order of $(\mathrm{C})<(\mathrm{A})<(\mathrm{H})<(\mathrm{E})<(\mathrm{F})<(\mathrm{B})<(\mathrm{G})<(\mathrm{D})$. All samples from the three regions showed nickel concentration above the permissible limit of $1.5 \mathrm{mg} / \mathrm{l}\left(150 \mathrm{mgkg}^{-1}\right)$ for residential and agricultural lands set by the US EPA and CEC. This indicates that the soil suffers from nickel contamination and may affect plants lives cultivated on the soil. 


\section{Manganese Levels}

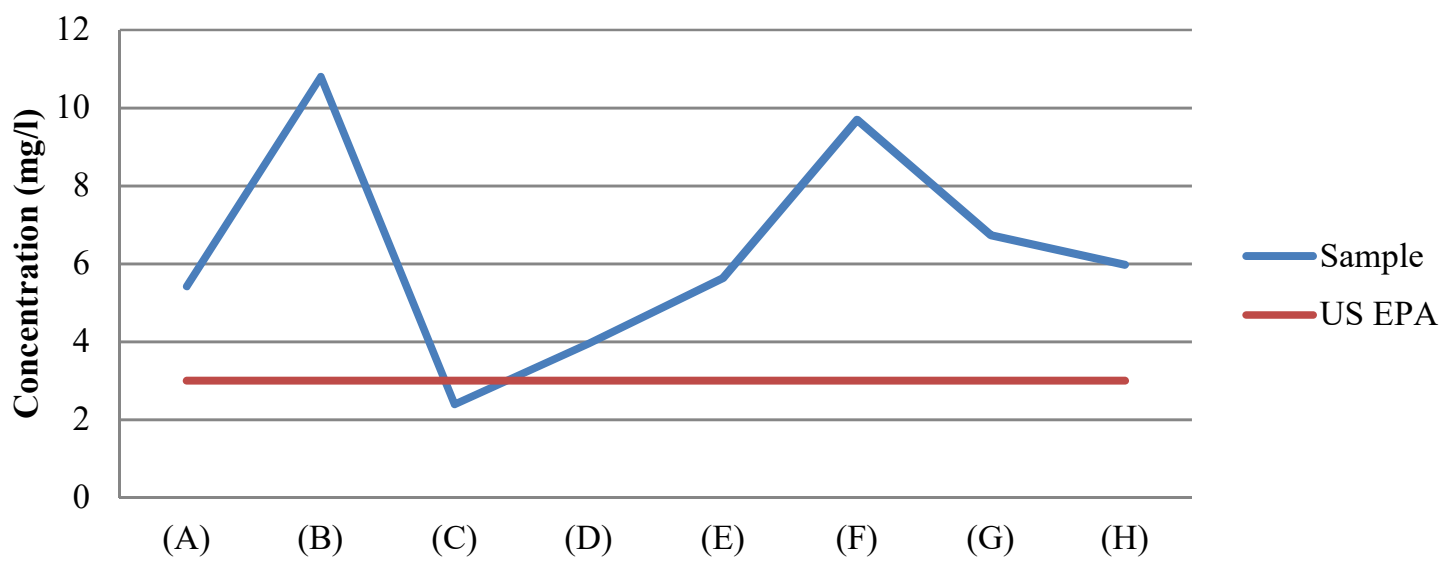

Figure 5: Manganese concentrations in soil samples relative to US EPA permissible limits

The concentration of Manganese $(\mathrm{Mn})$ obtained from all analyzed samples as shown in figure 5 ranged from $2.391 \mathrm{mg} / \mathrm{l}-10.802 \mathrm{mg} / \mathrm{l}\left(239.1 \mathrm{mgkg}^{-1}-1080.2 \mathrm{mgkg}^{-1}\right)$, and was found in the order: $(\mathrm{C})<(\mathrm{D})<(\mathrm{A})<(\mathrm{E})<$ $(\mathrm{H})<(\mathrm{G})<(\mathrm{F})<(\mathrm{B})$. All samples were above the tolerable limits of $1 \mathrm{mg} / 1-3 \mathrm{mg} / 1\left(100 \mathrm{mgkg}^{-1}-300 \mathrm{mgkg}^{-1}\right) \mathrm{set}^{-}$ by US EPA for agricultural lands except for sample (B) from Ameri mining site. Soil sample (F) from Enyigba and sample (B) from Ameri showed a considerably high Mn concentration of $9.703 \mathrm{mg} / \mathrm{l}$ and $10.802 \mathrm{mg} / \mathrm{l}$ respectively. The result suggest that the contamination of the soil could have resulted from the decay of shale, hence releasing more of the toxicity into the soil and rendering it unfit for agricultural practices as they may affect plant growth negatively.

\section{Lead Levels}

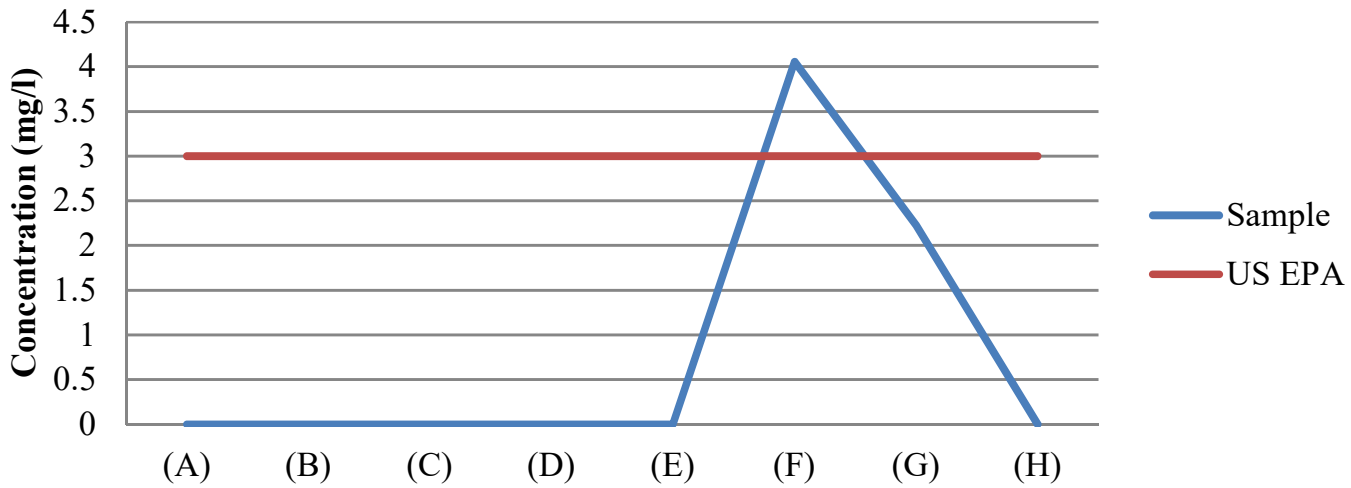

Figure 6: Lead concentrations in soil samples relative to US EPA permissible limits

Lead was detected in only two samples (figure 6): sample (F) and $(\mathrm{G})$ from Enyigba at concentration of 4.056 $\mathrm{mg} / \mathrm{l}$ and $2.226 \mathrm{mg} / \mathrm{l}\left(405.6 \mathrm{mgkg}^{-1}\right.$ and $\left.222.6 \mathrm{mgkg}^{-1}\right)$. The concentration of the metal analyzed for sample (F) was above the permissible limit of $0.3 \mathrm{mg} / \mathrm{l}-3 \mathrm{mg} / 1\left(30 \mathrm{mgkg}^{-1}-300 \mathrm{mgkg}^{-1}\right)$ set by the US EPA while that of sample (G) fell below the limit. The rest of the soil samples from the other regions did not show the presence of lead quantifiable as it was not detected by the spectrometer. This suggests that the concentration of lead in the soil sample (F) from Enyigba could affect agricultural practices and plant lives negatively in the region (Obasi et al.,2012). 


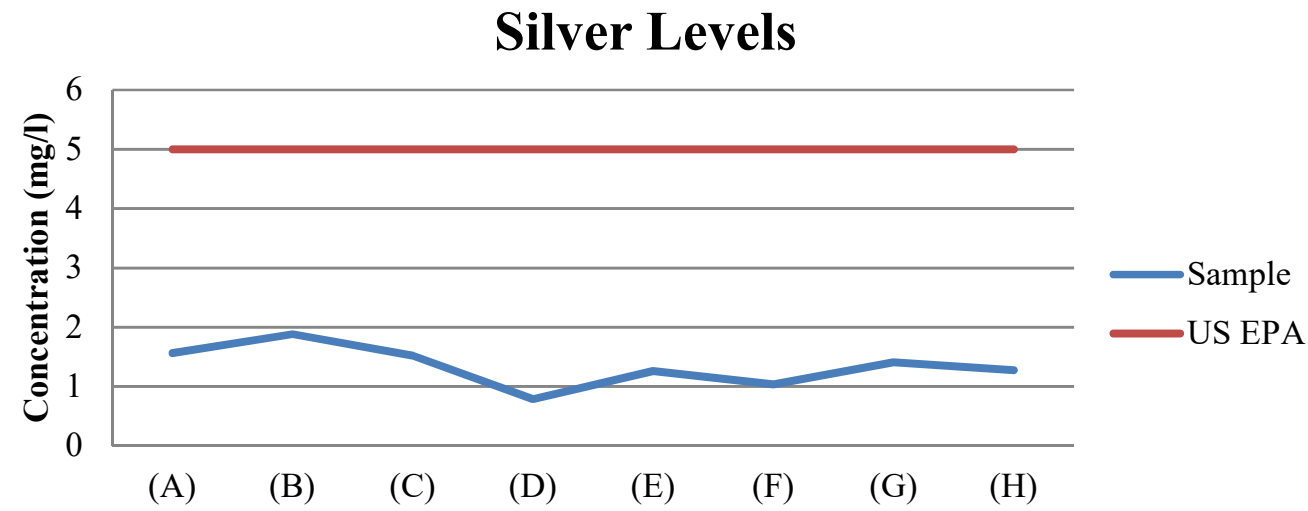

Figure 7: Silver concentrations in soil samples relative to US EPA permissible limits

Figure 7 revealed that the silver $(\mathrm{Ag})$ concentration in all the samples analyzed ranged from $0.788 \mathrm{mg} / \mathrm{l}-$ $1.882 \mathrm{mg} / \mathrm{l}\left(78.8 \mathrm{mgkg}^{-1}-188 \mathrm{mgkg}^{-1}\right)$. The silver $(\mathrm{Ag})$ content was in the order of $(\mathrm{D})<(\mathrm{F})<(\mathrm{H})<(\mathrm{E})<(\mathrm{G})<$ (C) $<$ (A) $<$ (B). It appeared that the silver content in all samples from the three regions was higher than the permissible limit in normal soil by Lindsay (1979). The soil sample (B) from Ameri harbored the highest silver content, which suggests a possible contamination of the soil as the mineral host rock decays gradually with time releasing its toxicity into the soil.

\section{CONCLUSION}

The total concentration of all the mobile heavy metals in soil revealed that mining activities in the $\mathrm{Pb}-\mathrm{Zn}$ mineralization regions of Ameri, Enyigba and Ishiagu in Ebonyi State, South-East Nigeria, were above the normal soil composition based on Bowen (1979), and in the order $\mathrm{Mn}>\mathrm{Zn}>\mathrm{Pb}>\mathrm{Ni}>\mathrm{Ag}>\mathrm{Co}$. The high values may indicate both geologic and anthropogenic origin. Many of the soil samples contained heavy metals at levels that could cause toxicity and impact negatively on the environment through their introduction above the threshold limit to the soil and water thereby causing severe pollution of the water and soil.

The main conclusion that can be drawn from this study is that the risk level of heavy metal leaching and groundwater contamination from the soil is very high with considerable likelihood of heavy metal transport by water percolating through the soils/mine waste since the dumping of the mine wastes is practiced. The people of Abakaliki who are known producers of rice and yams in southeastern Nigeria, would need a management plan against the transfer of metals into the ecosystem in order to alleviate the possible metal related health problems. This can be done by reducing the solubility and concentration of metals in the soil to reduce metal intake through the consumption of contaminated forages and soil.

\section{ACKNOWLEDGEMENT}

We express gratitude to the Kaduna State University, Department of Chemistry in which this study was carried out for the space and support granted during the course of the work. Authors also thank the National Geosciences Research Laboratories, Department of Geochemistry for their continued support and assistance leading to the success of this research.

\section{CONFLICT OF INTEREST}

The authors have no conflict of interest to be declared in regards to the publication of this manuscript.

$\begin{array}{ll}\text { ABBREVIATIONS } \\ \text { AAS } & \text { Atomic Absorption Spectrometer } \\ \mathrm{CEC} & \text { Council of the European Communities } \\ \mathrm{US} \mathrm{EPA} & \text { United States Environmental Protection Agency } \\ \mathrm{Conc} & \text { concentration } \\ \mathrm{HNO}_{3} & \text { Nitric acid } \\ \mathrm{HCl} & \text { Hydrochloric acid } \\ \mathrm{GPS} & \text { Global Positioning System } \\ \mathrm{mg} / 1 & \text { Milligram per liter } \\ \mathrm{mls} & \text { Milliliter } \\ \mathrm{mgkg} & \text { Milligram per kilogram } \\ \mathrm{g} / \mathrm{mol}^{-1} & \text { Gram per mole } \\ \mathrm{g} / \mathrm{cm}^{3} & \text { Gram per cubic centimeter }\end{array}$




$\begin{array}{ll}\mathrm{Km}^{2} & \text { Kilometer square } \\ \mathrm{m} & \text { Meter } \\ \mathrm{cm} & \text { Centimeter } \\ \mathrm{BDL} & \text { Below Detection Limit } \\ \mathrm{Ag} & \text { Silver } \\ \mathrm{Mn} & \text { Manganese } \\ \mathrm{Zn} & \text { Zinc } \\ \mathrm{Co} & \text { Cobalt } \\ \mathrm{Pb} & \text { Lead } \\ \mathrm{Ni} & \text { Nickel }\end{array}$

\section{REFERENCES}

Amos-Tautua, B.M.W., Inengite, A.K., Abasi, C.Y and Amirize, G.C. (2013). Evaluation of Polycyclic Aromatic Hydrocarbons and some heavy metals in roasted food snacks in Amassoma, Niger Delta, Nigeria. African Journal of Environmental Science and Technology, 7(10): 961- 966. Retrieved from http://www.academicjournals.org/AJEST

Bowen, H.J.M (1979). Environmental Chemistry of the Elements. Academic Press, London, pp320.

CEC (1986).Directive of 12th June, (1986) on the protection of the environment and in particular soil when sewage sludge is used in agriculture.Council of the European Communities.Official Journal of European Community, L181: 6-12.

Connell, D.W. and G.J. Miller, (1984). Chemistry of Ecotoxicology Pollution. John Wiley and Sons, New York.

During, R.A., Hob, T. and Gath, S. (2003). Sorption and bioavailability of heavy metals in long-term differently tilled soils amended with organic wastes. Science of Total Environment 313: 227-234.

Itumoh, E. J., Uraku, A. J., Omaka, O. N. and Nwabue, F. I. (2013). Trace Metal Toxicity in our Environment: Case Studies of Influx of Metals in Soils, Crops, Waters and Air in Ebonyi State. Global Journal of Bioscience and Biotechnology. Society for Science and Nature (SFSN) www.scienceandnature.org.

Itumoh, E.J., Izuagie, T., Omaka, N. O., Uba, A., Shuaibu, M., Dogonyaro, I. A., Isah, A., Dange, A. U. and Isah, S. I. (2011) Trace Metals Analysis of Soil and Water Samples from a Limestone Mining Site in Sokoto State Nigeria. Journal of Physical Sciences and Innovation 3, pp. 62-71.

Karaca, A. (2004). Effect of organic wastes on the extractability of Cadmium, Copper, nickel and Zinc in Soil.Geoderma 122: 297- 303.

Kennish, M J., (1992).Ecology of Estuaries Anthropogenic Effects. CRC Press, Boca Raton. pp.494

Lindsay, W.L. (1979). Chemical Equilibrium in Soils. John Wiley \& Sons, New York, pp449

Matthew, M.M., Henke, R. and Atwood, A. (2002). Effectiveness of commercial heavy Metal chelators with new insights for the future in chelate design.Journal of Hazadous Materials, 92 (2): 129-142.

Obasi, N.A., Akubugwo, E.I., Ugbogu, O.C. and Chinyere, G.C. (2012). Heavy metals bioavailability and phytoaccumulation potentials on selected plants on Burrow-pit Dumpsite in Aba and Ntigha Dumpsite in Isiala Ngwa of Abia State, Nigeria. Nigeria Journal of Biochemistry and Molecular Biology 27 (1):27-45. http://www.nsbmb.org/journals.php

Omaka, O. N. (2008). Sources and Effects of Lead Pollution in the Environment.A Review.Journal of Applied and Natural Sciences 3 (1), pp. 28-35.

Omaka, O. N. (2012) Atmospheric and Metallic Pollutants and Their Impacts on the Environment: Case Study of Abakaliki Metropolis. Accepted for publication in Journal of Applied and Natural Sciences.

Omaka, O.N., Egede, O.O., Itumoh, E.J., Mmuo, V.E. and Okeke, G.N. (2012) Cr, Pb and Cd in Root Crops Cultivated in Local Farms of Ezzamgbo and Izzi Areas of Ebonyi State, SE Nigeria. Accepted for publication in Journal of Research in Physical Sciences.

Onyeobi, T.U.S and Imeokparia,E.G. (2014) Heavy Metal Contamination and Distribution in Soils around Pb Zn Mines of Abakaliki District, South Eastern Nigeria.FG Volume 2 Issue 2, Apr. 2014 pp. 30-40 www.vkingpub.com (C) American V-King Scientific Publishing.

Sabir, S.M., Khan,S.W. and Hayat,I. (2003).Effect of environmental pollution on quality of meat in district Bagh.Parkistan Journal of Nutrition, 2(2): 98-101.

Salama, A. K. and Radwan, M. A. (2005) Heavy Metals $(\mathrm{Cd}, \mathrm{Pb})$ and trace Elements $(\mathrm{Cu}, \mathrm{Zn})$ Contents in Some Foodstuffs from Egyptian Market. Emir.Journal of Agricultural Science 17 (1), pp. 34-42.

$\mathrm{Su}$, D.C. and Wong, J.W.C. (2003). Chemical speciation and phytoavailability of $\mathrm{Zn}, \mathrm{Cu}, \mathrm{Ni}$ and $\mathrm{Cd}$ in Soil amended with fly-ash stabilized sewage sludge. Environment International Journal.Vol 29; 895-900.

US EPA (1986). Test methods of evaluation of solid waste. In: Contaminated land policies in some industrialized countries. Visser, W.J.F. (edition). TCB report RO2 UK. pp 38-41. 